\title{
The Foresight Methodology in Strategic Planning at Regional Level
}

Submitted 15/05/20, 1st revision 19/06/20, 2nd revision 17/07/20, accepted $30 / 07 / 20$

\author{
M.A. Komissarova ${ }^{1}$, M.M. Kulikov², M.M. Afanasiev ${ }^{3}$, N.V. Guzenko ${ }^{4}$
}

\begin{abstract}
:
Purpose: The article aims to use foresight as one of the most effective tools for long-term forecasting of regions and industries development, and the formation of "future maps" with the subsequent development of scenarios of strategic development of the region.

Design/Methodology/Approach: The use of foresight in Europe and the USA, as well as the prospects for its use in Russia for the purpose of regional strategic planning is to identify those factors that influate the economic development at the regional level, to reflect the main advantages and disadvantages of foresight methodology and to formulate recommendations on the implementation of foresight methodology in the region.

Findings: A structural-logical scheme for foresight research at regional and sectoral levels has been formed, which will provide an opportunity to improve the methods and technologies of strategic development in an unstable economy as in the example of Russian regions. A scheme of the foresight study was proposed by the authors to attract investors to the regional development projects. In authors' opinion the influence of sectoral and regional perspectives and the innovative activity of companies in various industries will help to create reserves and a base to ensure the economic sustainability of the analyzed regions.

Practical Implications: The results may be implemented into managerial practices in order to improve and increase the effectiveness of regional strategic planning.

Originality/Value: The main contribution of this study is in the shift of emphasis on conceptualizing and incorporating the foresight methodology to the theory of strategic planning at regional level.
\end{abstract}

Keywords: Foresight methodology, strategic planning, regional projects.

JEL Code: O20, R58.

Paper type: Research article.

\footnotetext{
${ }^{1}$ Doctor of Science (Economics), Professor, Head of Department of "Personnel management”, Platov South-Russian state polytechnic university, Novocherkassk, e-mail:mari543@yandex.ru ${ }^{2}$ Candidate of Science (Economics), Associate Professor of Department of "Personnel management”, Platov South-Russian state polytechnic university, Novocherkassk, e-mail: kulikovmichael@mail.ru ${ }^{3}$ Assistant of Department of "Personnel management", Platov South-Russian state polytechnic university, Novocherkassk, e-mail: mishaafanasev@yandex.ru ${ }^{4}$ Ph.D., in economics, Associate Professor of Department of Commerce and Logistics, Rostov State University of Economics, Rostov-on-Don, e-mail: $\underline{\text { musamav@mail.ru }}$
} 


\section{Introduction}

It is considered that the main direction of development of the territory depends on the overall development strategy, which is related with the main activities and is focused on the achievement of a specific goal. The current political situation in Russian Federation has significantly affected economic relations both within the country and international. This influences the formation of regional policy. The current state of the economy, which is under the West countries' sanctions motivates the Russian regions to redirect the strategic development (Chernova, 2010). Forecast development is one of the most important stages of the implementation of the territorial development strategy.

Alongside the global challenges of the transition of high technologies to Russia, when in a short time it is necessary to improve the material and technical base in the modern conditions, we believe that the foresight can be an effective tool for putting into practice the necessary structural changes that create the innovative level of the Russian economy (Apokin and Belousov, 2009).

\section{Materials and Methods}

Speaking about the formation of the development strategies of the Russian regions, we would like to dwell on the concept of "foresight", which is innovative for the Russian economy. The term "foresight" is translated from English as "a look into the future." The most interesting for us is the definition of foresight, formulated by Martin and Johnston (1999). They focus on the foresight aspect of "foresight", aimed at establishing strategic economic zones (SEZ). Although according to the authors, it weakly affects other foresight tools. This definition is not able to characterize the versatility of foresight, as one of the most important tools used today in strategic planning.

On the territory of various states, foresight is based on a variety of methodologies and tools, based on different organizational principles (Chulok, 2009). Its essence lies in the collective (public) preparation and analysis of long-term plans, a set of strategic alternatives, the development of an integrated approach to scenario forecasting and discussion of the most positive development options. The foresight methodology is now used in most developed countries of the world and the accumulated experience is successfully adopted by developing countries (Brummer, Connola and Salo, 2010).

An important role in the compilating of long-term forecasts and the formulation of the effective development strategies in Western Europe is played by using various kinds of innovations, technological leadership to create competitive advantages on world markets due to globalization and integration of economic processes. At the same time, competitive efforts lead to a decrease in the life cycle of the products produced (Cuhls, 2003). 
In the early 1980s, foresight was first used in the United States as a national research project in the field of critical technologies. This was followed through the use of foresight by the countries of Western Europe, Great Britain, Germany (Boykova and Salazkin, 2008), France, Spain, and Hungary. Japan is also high experienced in this field. Returning to the use of foresight in the United States, we can see that an analysis of trends emerging not only in the economic but also in the political spheres of this state can significantly affect the situation in the United States and throughout the world community (Popper, 2007). However, the American foresight experience is quite specific, since it relies on such postulates as "US world domination" and "retaining leading market positions."

Despite national differences in approaches to foresight, several basic principles of this new method can be distinguished. It may have the following objectives:

- assessment of the development of a specific scientific and technical direction (provides for the development of a "technological map");

- assessment of the prospects of the sphere of science and technology (allocation of resources for $\mathrm{R} \& \mathrm{D}$ projects);

- assessment of the prospects for scientific and technological development in the socio-economic context (making strategic decisions at the macro level).

Foresight allows you to collect the necessary information for decision-making on the status and directions of state-funded $\mathrm{R} \& \mathrm{D}$, create a new culture of interaction between scientists and business and identify the resources needed to achieve the objectives. The main end product of foresight projects is the development of recommendations for national governments and EU governing bodies, the development of scenarios and trends, the determination of R \& D priorities (Van Pai, 2012). At the same time, compiling a list of critical technologies, technological roadmaps, and forecasts is a secondary goal of the project. In the private sector, along with recommendations, trend analysis is also in the first place, and in the research sector, trend analysis is in the lead (Karasev and Sokolov, 2009).

The development of foresight forecasts is still being carried out within national frameworks, mainly at the request of governments, since the development of a country's long-term scientific and technical strategy largely depends on its national characteristics. The work carried out in the EU R \& D Framework programs is aimed at developing methodologies and disseminating best practices. International cooperation in "developing the future" is usually carried out on a subregional basis.

Recently, there has been some increase in activity with respect to foresight research in Russia by federal, regional and municipal authorities. The majority of foresight often passes through only the stage of pre-website. This happens because we do not yet have the theoretical and methodological aspects worked out to the end in the implementation of foresight projects. At the same time, technological foresight dominates (Kryukov, Patrakeeva, 2016). All this speaks of the problem of the need 
to unite forces in order to train people of appropriate qualifications within the framework of this scientific issue.

The long-term forecast of the scientific and technological development of the Russian Federation for the period up to 2025, prepared by the Ministry of Education and Science of the Russian Federation in 2007-2008 (Sokolov and Chulok, 2012), became the most ambitious and comprehensive foresight survey. It was preceded by instructions from the Government of the Russian Federation and professional discussions about the goals and methods of foresight research, which indicates that the authorities and the professional community are not indifferent to not only the problems and prospects for the development of science, technology and innovation, but also the foresight research issues and their applicability to Russian realities (Pereslegin, 2009).

\section{Results}

Currently, at the federal level, Russia is developing general-type foresight schemes and special nanotechnologies for the field; a Foresight IT program has been launched (information technology foresight) (Karasev and Vishnevsky, 2010). Some Russian regions work out and implement plans and programs of development, including using methodology of foresight (Kulikov, 2015).

The main advantages of foresight research include:

- Identification of possible future changes as a result of the integration of efforts by all stakeholders of the foresight project;

- requires the integrated participation of all stakeholders in society;

- contributes to the harmonization of different opinions of all stakeholders;

- helps to form effective strategies for the development of various sectors of the national economy;

- Identifies the expected technological horizons;

- helps to make major decisions that require helicopter view;

- determines the degree of probability, estimates the possibility of various types of risks;

- Participation in a foresight project of various kinds of specialists, research scientists, media, business leaders.

The negative aspects of foresight research include:

- the need for a significant amount of investment;

- long terms (lag) of implementation;

- high degree of response to the use of various tools;

- insufficient number of high-tech enterprises in Russia. 
However, these shortcomings do not reduce the positive nature of foresight research and this forecasting method is currently the most promising. At the same time, one should distinguish between those directly involved in the project and those whose interests are indirectly subordinate to the results of this study and the identification of possible future situations. The combination of representatives of multi-scale business, government officials, scientists, politicians and the infrastructure of research systems is the basis of the project (Komissarova, Zaitsev and Ovchinnikov, 2016).

Figure 1. Scheme of the foresight study at the regional level (developed by authors)

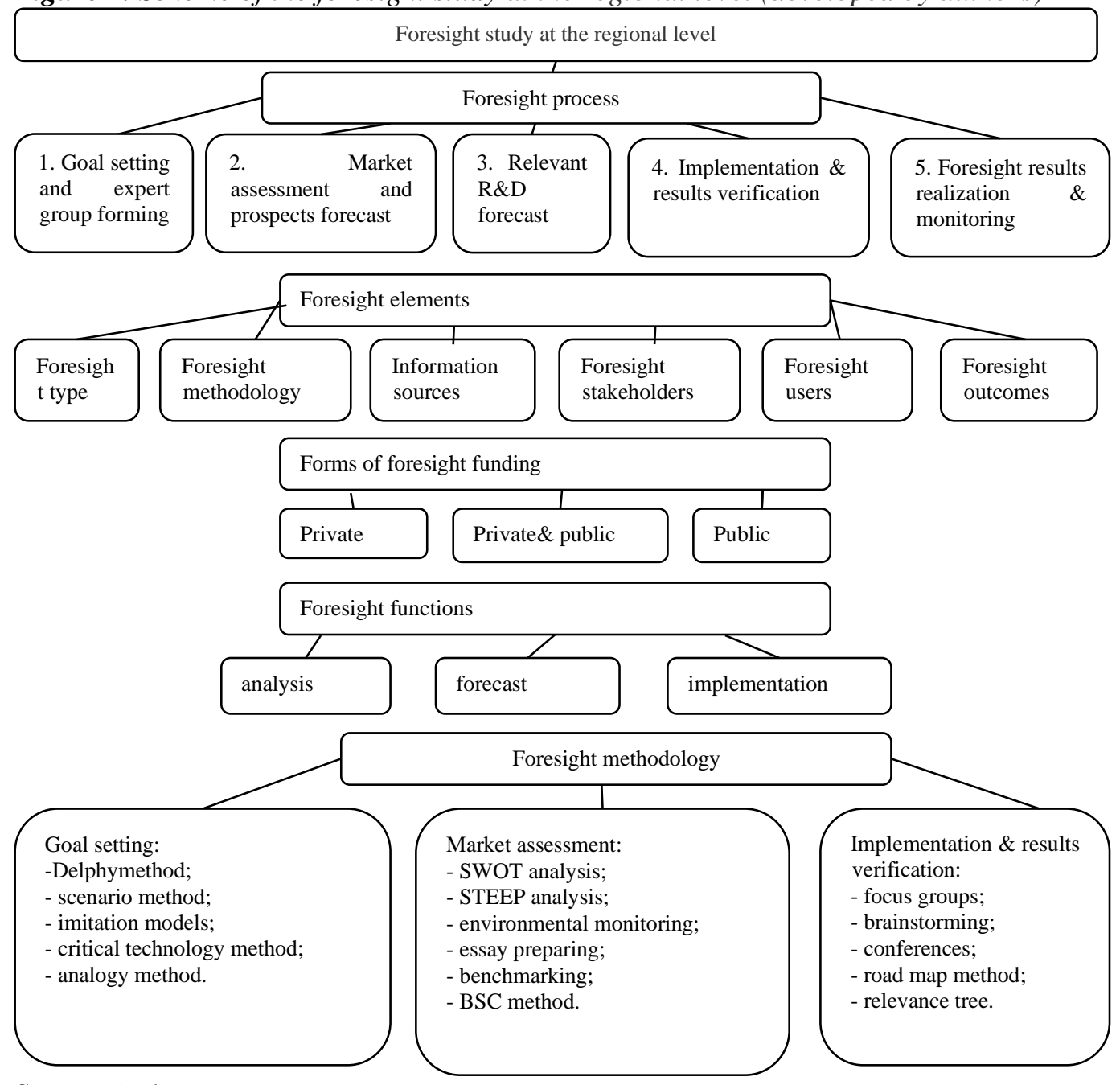

Source: Authors.

Having studied a number of participants on foresight and other scientific publications, the authors considered it possible to summarize and present them in the diagram shown in Figure 1. 
Coming back to the region-wide foresight survey that we are interested in, we would like to present the process in more detail. Of course, today foresight research is the field with the most promising tools for exploring the future. The processes of globalization and integration in the global space, as well as the development of the Internet have greatly facilitated this task, since they allowed all the initiators of such projects to have access to various kinds of information.

We believe that the structural and logical scheme for a foresight study at the regional and sectoral levels provided by the authors will give an opportunity to improve methods and technologies for the strategic development of enterprises in the analyzed industry and increase their adaptability in an unstable economy.

\section{Discussion}

Returning to the question of the possibility of using foresight, we would like to note that one of the important conditions for the application of this methodology is the awareness of the benefits of a foresight by society (authorities, heads of enterprises, administration, workers and communities). Having integrated their efforts, all interested parties can centrally approach the assessment of the prospects for the future functioning of a state, region or industry, however, the use of foresight research tools is quite expensive, since for holding various kinds of discussions, meetings and conferences, as well as the formation of an analytical base the research consumes a lot of finance, time and intellectual resources.

Therefore, in the course of this study, the issue of estimating the investment attractiveness of the analyzed object and its competitive advantages becomes quite relevant.

\section{Conclusion}

Based on the ideas of foreign and Russian scientists, we believe that the need to use foresight as a method of prognostic analysis when creating long-term development scenarios for the territory is very useful. This forced the authors to form structural and logical scheme for foresight research at the regional and industrial levels, which will provide an opportunity to improve methods and technologies of strategic development of Russian regions and improve their adaptability in an unstable economy.

In authors' opinion, the influence of sectoral and regional perspectives and the innovative activity of companies in various industries will help to create reserves and a base to ensure the economic sustainability of the analyzed regions. A foresight study will serve as a kind of tool to help recreate the "pictures of the future" and form a long-term strategy for the development of enterprises in a single territory.

\section{References:}


Apokin, A.Yu., Belousov, D.R. 2009. Scenarios of the development of the world and Russian economy as a basis for scientific and technological forecasting. Foresight, 3(3), 12-29.

Boykova, M.V., Salazkin, M.G. 2008. Foresight in Germany. Master Class Foresight, 1(5).

Brummer, V., Connola, T., Salo, A. 2010. Diversity in Foresight Studies. The practice of selecting innovative ideas. Foresight, 4, 59.

Chernova, O.A. 2010. Balanced development of the regional economy: an innovationoriented strategy. Dr. thesis, Southern federal university, Rostov-on-Don, 200-205.

Cuhls, K. 2003. From Forecasting to Foresight Processes - New Participant Foresight Activities in Germany. Journal of Forecasting, 22, 94.

Jasińska-Biliczak, A., Malik, K. 2020. Measuring the Integrated Effectiveness of Regional Development: Directions for Regional Government. European Research Studies Journal, 23(1), 389-403, DOI: 10.35808/ersj/1557.

Karasev, O.I., Sokolov, A.V. 2009. Foresight and technological roadmaps for nano industry Russian nano technology. Foresight, 3-4(4), 8-15.

Karasev, O.I., Vishnevsky, K.O. 2010. Forecasting the development of new materials using the Foresight methods. Foresight, 2(4), 58-67.

Komissarova, M.A., Zaitsev, R.G., Ovchinnikov, P.V. 2016. The Social Sciences, 28(11), 6831-6838.

Kryukov, S.V., Patrakeeva, O.Yu. 2016. System-dynamic model of the regional economy (on example of the Rostov region). Problems of forecasting, 3(156), 71-76.

Kulikov, M.M. 2015. Concept of development of industrial policy in Rostov region. Mining information and analytical bulletin (scientific and technical journal), 9, 269-274.

Malik, K., Mach, L., Szewczuk-Stępień, M., Bębenek, P. 2020. Specialization Integrated Strategy of Innovations: Effective Model for Emerging Regional Economy Development? European Research Studies Journal, 23(2), 78-97. DOI: $10.35808 /$ ersj/1581.

Martin, B.R., Johnston, R. 1999. Technology foresight for wiring up the national innovation system: experiences in Britain, Austria, and New Zealand. Technological Forecasting and Social, 51-56.

Pereslegin, S.B. 2009. New maps of the future, or Anti-Rand. Moscow, AST MOSCOW, Terra Fantastica, Saint-Petersburg, 520-526.

Popper, R. 2007. Methodology: Common Foresight Practices and Tools. International Handbook on Foresight and Science Policy: Theory and Practice. Edward Elgar.

RMP Tech. 2019. Road mapping technology. Available online: http://www.unido.org/fileadmin/import/16963_TechnologyRoadmapping.pdf.

Rusventure. 2019. Scenario of innovation development and globalization of the Russian information technology industry. Available online: http://www.rusventure.ru/ru/programm/analytics/docs/scenarii_innov_razv.pdf.

Sokolov, A.V., Chulok, A.A. 2012. The long-term forecast of the scientific and technological development of Russia for the period up to 2030: key features and first results. Foresight, 1(6), 12-25.

Stocking, A.A. 2009. Forecast of the prospects for the scientific and technological development of key sectors of the Russian economy: future challenges. Foresight, 3(3), 30-36.

TF 2030. 2019. Technological foresight until 2030: Japan. Available online: http://www.foresight-russia.ru.

Van Pai, V. 2012. Emerging trends and "jokers" as tools for shaping and changing the future. Foresight, 1(6), 60-73. 